\title{
Daya Optimal Pembangkit Listrik Tenaga Mikro Hidro Terhadap Studi Kelayakan dan Perancangan Turbin pada Proyek Mikrohidro
}

\section{Optimal Power of Micro Hydro Power Plant on Feasibility Study and Turbine Design in Microhydrous Projects}

\author{
Wisnaningsih $^{1 *}$, Achmad Tarmizi ${ }^{1}$ \\ ${ }^{1}$ Fakultas Teknik Universitas Sang Bumi Ruwa Jurai \\ Email: Wisnanigsih@gmail.com
}

\begin{abstract}
Abstrak
Penelitian ini bertujuan meneliti dan merancang jenis turbin yang sesuai pada proyek pembangunan Pembangkit Listrik Tenaga Mikro Hidro (PLTMH) di Kabupaten OKU Selatan sehingga dapat menghasilkan daya yang optimal. Batasan permasalahan dibatasi pada studi kelayakan dan perancangan turbin pada proyek mikrohidro di Kabupaten OKU Selatan Provinsi Sumatera Selatan. Penelitian ini didasarkan pada hasil studi kelayakan yang dilakukan penulis dengan melakukan studi lapangan untuk mengambil data-data di lokasi dengan memperhatikan aspek teknis, ekonomis dan sosial, kemudian dilakukan studi literatur dan analisis data untuk menentukan jenis turbin dan karakteristik yang paling tepat untuk PLTMH dilokasi tersebut. Dari hasil analisis data dan dengan melakukan perhitungan yang teliti serta dengan memperhatikan kondisi lokasi proyek PLTMH tersebut, turbin yang paling tepat untuk digunakan adalah turbin tipe turbin propeller, turbin ini selain memiliki konstruksi yang sederhana, dapat pula didesain untuk kapasitas yang cukup besar dan lebih mudah dalam proses fabrikasi.
\end{abstract}

Kata kunci: Mikrohidro, Turbin Propeller, Oku Selatan

\begin{abstract}
This study aims to research and design the appropriate type of turbine in the Micro Hydro Power Plant (PLTMH) development project in South OKU Regency so that it can produce optimal power. The limitation of the problem is limited to the feasibility study and turbine design on a micro hydro project in South OKU Regency, South Sumatra Province. This research is based on the results of a feasibility study conducted by the author by conducting a field study to collect data at the location by paying attention to technical, economic and social aspects, then literature studies and data analysis are carried out to determine the type of turbine and the most appropriate characteristics for MHP at that location. From the results of data analysis and by doing careful calculations and taking into account the conditions of the PLTMH project site, the most appropriate turbine to use is a propeller turbine type turbine, this turbine in addition to having a simple construction, can also be designed for a large enough capacity and easier in the manufacturing process.
\end{abstract}

Keywords: Microhydro, Propeller Turbine, South OKU 


\section{PENDAHULUAN}

Energi listrik telah menjadi kebutuhan pokok dan memainkan peranan yang penting dalam kehidupan manusia, di Indonesia PLN baru mampu menyuplai 53\% dari total kebutuhan listrik masyarakat, sementara $47 \%$ penduduk Indonesia hidup di daerah yang tidak terjangkau jaringan listrik [1]. hal ini dikarenakan keterbatasan infrastruktur dan kapasitas pembangkit listrik yang tersedia, padahal sumber energi pembangkit tidak melulu dari bahan bakar fosil, seperti halnya pemakaian solar dan batubara dari PLTD dan PLTU. Potensi tenaga air yang sangat besar di Indonesia yang diperkirakan mencapai 75.000 MW, sebenarnya dapat dimanfaatkan untuk pengembangan sistem pembangkit listrik tenaga air, sedangkan saat ini baru 2,5\% saja potensi tersebut telah dikembangkan [2].

Sebenarnya Pembangkit Listrik Tenaga Mikrohidro (PLTMH) memiliki potensi besar untuk dikembangkan di daerah-daerah pedesaan yang belum terjangkau oleh infrastruktur PLN, PLTMH memanfaatkan aliran sungai setempat dengan cara mengalihkan sebagian aliran air menuju turbin, lalu selepas dari turbin, air dikembalikan kealiran semula, sehingga keberadaannya tidak berdampak pada lingkungan setempat.

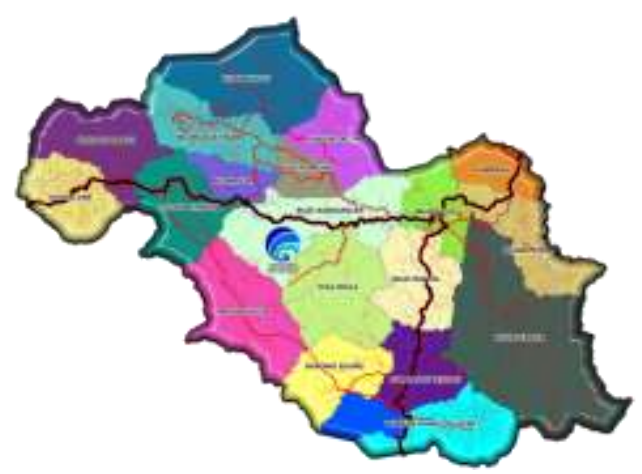

Gambar 1. Peta kabupaten OKU Selatan

PLTMH kebanyakan dibangun didaerah-daerah pelosok yang memiliki potensi air sehingga dalam pemakaian turbin air para perancang banyak yang menyarankan bahwa turbin air tipe Turbin propeller cocok untuk PLTMH, dikarenakan fasilitas didaerah pelosok sangat terbatas dan juga turbin air tipe Turbin propeller ini lebih muda dalam fabrikasi [3].

Untuk memenuhi kebutuhan listrik masyarakat yang terus tumbuh, Pemerintah sedang mengupayakan penambahan kapasitas listrik sebesar 7.000 MW per tahun 35.000 MW dalam 5 tahun. Pembagian pengadaan tambahan tenaga listrik dibagi berdasarkan zona, Sumatera direnacanakan sebesar 8,75 GW, Kalimantan 1,87 GW, Sulawesi 2,70 GW, Jawa-Bali 20,91 GW, Nusa Tenggara 0,70 GW, Maluku 0,28 GW dan Papua 0,34 GW [4].

Kementerian Energi dan Sumber Daya Mineral (ESDM) merilis Keputusan Menteri ESDM Nomor 43K/20/MEM/2019 tentang Rencana Umum Ketenagalistrikan Nasional Tahun 2019 sampai dengan Tahun 2038. Dalam keputusan itu, ESDM memproyeksikan rata-rata pertumbuhan kebutuhan energi listrik nasional sekitar 6,9 persen per tahun. Proyeksi tersebut tercapai apabila rata-rata pertumbuhan ekonomi nasional sekitar 6 persen, rata-rata inflasi sekitar 3,5 persen, rata-rata pertumbuhan penduduk sekitar 0,8 persen, target rasio elektrifikasi sekitar 99,9 persen pada 2019 dan 100 persen pada 2020. Selain itu juga mengakomodasi semua potensi demand untuk kawasan ekonomi khusus (KEK), kawasan industri, smelter, dan kendaraan listrik [4].

Pertumbuhan konsumsi energi sektor rumah tangga masih menjadi yang tertinggi dibanding sektor lainnya selama semester I/2019, yakni sebesar 5,85 persen. Pertumbuhan penjualan kedua, yakni pada sektor bisnis sebesar 5,75 persen. Sementara itu, pertumbuhan industri menjadi yang paling rendah, yakni 1,28 persen [4].

\section{Pembangkit Listrik Tenaga Mikrohidro (PLTMH)}


Mikrohidro atau yang dimaksud dengan Pembangkit Listrik Tenaga Mikrohidro (PLTMH) adalah suatu pembangkit listrik skala kecil yang menggunakan tenaga air sebagai tenaga penggeraknya seperti, saluran irigasi, sungai atau air terjun alam dengan cara memanfaatkan tinggi terjunan (head) dan jumlah debit air. Mikrohidro merupakan sebuah istilah yang terdiri dari kata mikro yang berarti kecil dan hidro yang berarti air. Secara teknis, mikrohidro memiliki tiga komponen utama yaitu air (sebagai sumber energi), turbin dan generator. Mikrohidro mendapatkan energi dari aliran air yang memiliki perbedaan ketinggian tertentu. Pada dasarnya, mikrohidro memanfaatkan energi potensial jatuhan air (head) [5].

Semakin tinggi jatuhan air maka semakin besar energi potensial air yang dapat diubah menjadi energi listrik. Di samping faktor geografis (tata letak sungai), tinggi jatuhan air dapat pula diperoleh dengan membendung aliran air sehingga permukaan air menjadi tinggi. Air dialirkan melalui sebuah pipa pesat kedalam rumah pembangkit yang pada umumnya dibagun di bagian tepi sungai untuk menggerakkan turbin atau kincir air mikrohidro [6].

Energi mekanik yang berasal dari putaran poros turbin akan diubah menjadi energi listrik oleh sebuah generator. Mikrohidro bisa memanfaatkan ketinggian air yang tidak terlalu besar, misalnya dengan ketinggian air 2.5 meter dapat dihasilkan listrik 400 watt. Relatif kecilnya energi yang dihasilkan mikrohidro dibandingkan dengan PLTA skala besar, berimplikasi pada relatif sederhananya peralatan serta kecilnya areal yang diperlukan guna instalasi dan pengoperasian mikrohidro.

Hal tersebut merupakan salah satu keunggulan mikrohidro, yakni tidak menimbulkan kerusakan lingkungan. Perbedaan antara Pembangkit Listrik Tenaga Air (PLTA) dengan mikrohidro terutama pada besarnya tenaga listrik yang dihasilkan, PLTA di bawah ukuran $200 \mathrm{KW}$ digolongkan sebagai mikrohidro. Dengan demikian, sistem pembangkit mikrohidro cocok untuk menjangkau ketersediaan jaringan energi listrik di daerah-daerah terpencil dan pedesaan [7].

Beberapa keuntungan yang terdapat pada pembangkit listrik tenaga listrik mikrohidro adalah sebagai berikut [5]:

1. Dibandingkan dengan pembangkit listrik jenis yang lain, PLTMH ini cukup murah karena menggunakan energi alam.

2. Memiliki konstruksi yang sederhana dan dapat dioperasikan di daerah terpencil dengan tenaga terampil penduduk daerah setempat dengan sedikit latihan.

3. Tidak menimbulkan pencemaran.

4. Dapat dipadukan dengan program lainnya seperti irigasi dan perikanan.

5. Dapat mendorong masyarakat agar dapat menjaga kelestarian hutan sehingga ketersediaan air terjamin.

\section{Pengukuran Debit air}

Terdapat banyak metode pengukuran debit air. Sistem konversi energi air skala besar pengukuran debit dapat berlangsung bertahun-tahun. Sedangkan untuk sistem konversi energi air skala kecil waktu pengukuran dapat lebih pendek, misalnya untuk beberapa musim yang berbeda saja.

\section{Dam / Bendungan Pengalih dan Intake}

Bendungan berfungsi untuk menaikkan/mengontrol tinggi air dalam sungai secara signifikan sehingga memiliki jumlah air yang cukup untuk dialihkan ke dalam intake pembangkit mikro hidro di bagian sisi sungai ke dalam sebuah bak pengendap (Settling Basin). Sebuah bendung dilengkapi dengan pintu air untuk membuang kotoran/lumpur yang mengendap. Perlengkapan lainnya adalah penjebak/saringan sampah. PLTMH umumnya merupakan pembangklit tipe run 
off river sehingga bangunan bendung dan intake dibangun berdekatan. Dengan pertimbangan dasar stabilitas sungai dan aman terhadap banjir, dapat dipilih lokasi untuk bendung (Weir) dan intake.

Tujuan dari intake adalah untuk memisahkan air dari sungai atau kolam untukdialirkan ke dalam saluran, penstock atau bak penampungan. Tantangan utama dari bangunan intake adalah ketersediaan debit air yang penuh dari kondisi debit rendah sampai banjir. Juga sering kali adanya lumpur, pasir dan kerikil atau puingpuing dedaunan pohon sekitar sungai yang terbawa aliran sungai. Berikut gambar sari dam/intake pada gambar di bawah ini.

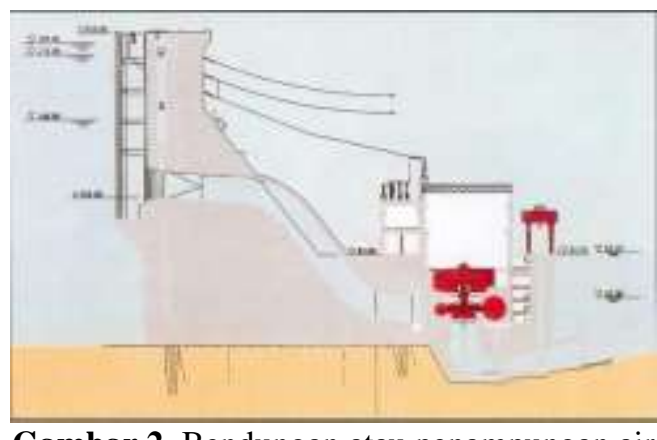

Gambar 2. Bendungan atau penampungan air

\section{Pipa Pesat (Penstock)}

Penstock dihubungkan pada sebuah elevasi yang lebih rendah ke sebuah turbin air. Kondisi topografi dan pemilihan skema PLTMH mempengaruhi tipe pipa pesat (penstock). Umumnya sebagai saluran ini harus didesain/dirancang secara benar sesuai kemiringan (head) sistem PLTMH [8].

Pipa penstock merupakan salah satu komponen yang mahal dalam pekerjaan PLTMH dan bahan yang digunakan harus dipertimbangkan juga, oleh karena itu desainnya perlu dipertimbangkan terhadap keseimbangan antara kehilangan energi dan biaya yang diperlukan. Parameter yang penting dalam desain pipa penstock terdiri dari material yang digunakan, diameter dan ketebalan pipa serta jenis sambungan yang digunakan,gambar dari pipa pesat (penstock) dapat diihat pada gambar di bawah ini.

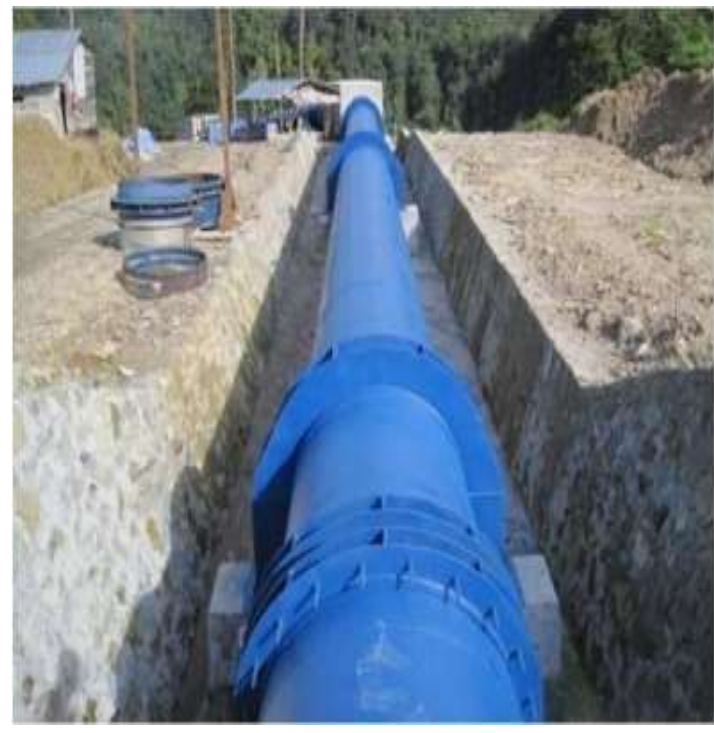

Gambar 3. Pipa pesat (penstock)

\section{Turbin}

Turbin air berperan untuk mengubah energi air (energi potensial, tekanan dan energi kinetik) menjadi energi mekanik dalam bentuk putaran poros. Putaran poros turbin ini akan diubah oleh generator menjadi tenaga listrik. Berdasarkan prinsip kerjanya, turbin air dibagi menjadi dua kelompok [3].

1. Turbin implus (cross-flow, pelton \& turgo) Untuk jenis ini, tekanan pada setiap sisi sudu gerak runnernya pada bagian turbin yang berputar sama.Jenis turbinimpuls ini dapat dilihat pada gambar berikut:

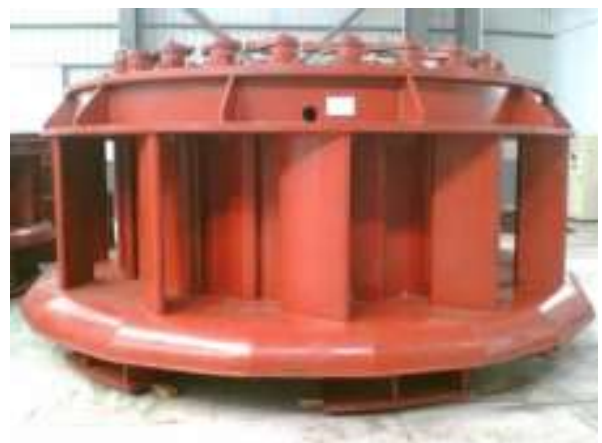

Gambar 4. Turbin Impuls

2. Turbin Reaksi (francis, kaplan propeller). Untuk jenis ini, digunakan untuk berbagai keperluan (wide range) 
dengan tinggi terjun menengah (medium head).

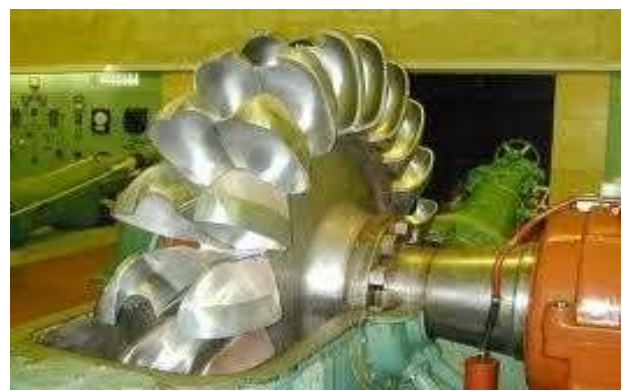

Gambar 5. Turbin Reaksi

Turbin merupakan bagian penting dari sistem mikro hidro yang menerima energi potensial dari air dan mengubahnya menjadi energi putaran (mekanik).Kemudian energi mekanik ini akan memutar sumbu turbin pada generator. Terdapat beberapa jenis turbin menurut teknologinya, antara lain [8]:

1. Turbin Tradisional, biasanya terbuat dari bambu atau kayu.

2. Turbin Modern, biasanya digunakan pada proyek - proyek PLTMH berdana besar. Turbin jenis ini yang paling banyak digunakan adalah turbin jenis Kaplan, Francis, Cross Flow dan Pleton

3. Turbin Modifikasi, di buat dengan memodifikasi jenis turbin yang telah ada. Di Indonesia, Balitbang telah membuat beberapa turbin jenis ini.

Dari hasil-hasil penelitian tersebut diatas, para peneliti hanya melakukan penelitian dan perencanaan tanpa melakukan kegiatan studi kelayakan dan meskipun dilaksanakan akan tetapi tidak diimplementasikan pada proyek PLTMH, pada kegiatan penelitian ini penulis melakukan kegiatan studi kelayakan untuk merancang turbin pada proyek PLTMH di Kabupaten OKU Selatan.

\section{METODE PENELITIAN}

Penelitian ini dilakukan di Kabupaten Ogan Komering Ulu Selatan yang dialiri oleh dua sungai besar yaitu Sungai Selabung dan Sungai Saka yang bermuara ke Sungai Komering. Selain itu, masih terdapat sekitar 20 sungai dan anak sungai lainnya yang tersebar di seluruh wilayah Kabupaten Ogan Komering Ulu Selatan. Di Kabupaten ini juga terdapat beberapa air terjun dan danau, baik yang besar maupun kecil, sehingga daerah ini merupakan daerah pariwisata potensial di Provinsi Sumatera Selatan.

Jalannya penelitian dengan melakukan survey awal lapangan keseluruh kecamatan di Kabupaten OKU Selatan, mengumpulkan data-data dari instansi terkait dan literatur tentang semua yang berhubungan dengan PLTMH, setelah itu melakukan studi kelayakan dan survey detail pada salah satu lokasi, untuk mengetahui kelayakan pembangunan proyek pada lokasi tersebut.

Selanjutnya peneliti melakukan analisis data yang didapat untuk menentukan dan merancang jenis turbin yang tepat digunakan pada pembangunan PLTMH di Kabupaten OKU Selatan, hasil rancangan turbin pada proyek, mengingat kegiatan penelitian ini adalah salah satu kegiatan yang menyatu dengan proyek, maka dapat dengan cara dibuat sendiri ataupun dengan melakukan pemesanan pada pihak yang memproduksi turbin Turbin propeller.

\section{HASIL DAN PEMBAHASAN}

Berdasarkan hasil pengukuran debit pembangkitan adalah $500 \mathrm{l} / \mathrm{dt}$ dan tinggi jatuh hidrolik 3,6 m. Sehingga jenis turbin ditetapkan tipe propeller, turbin tipe ini bisa menggunakan poros vertikal ataupun poros horizontal. Analisa desain turbin hidro propeller (dimensi sudu turbin, poros turbin dan lainnya) didasarkan pada kriteria kecepatan spesifik, kecepatan putaran turbin dan rencana daya terbangkit. 


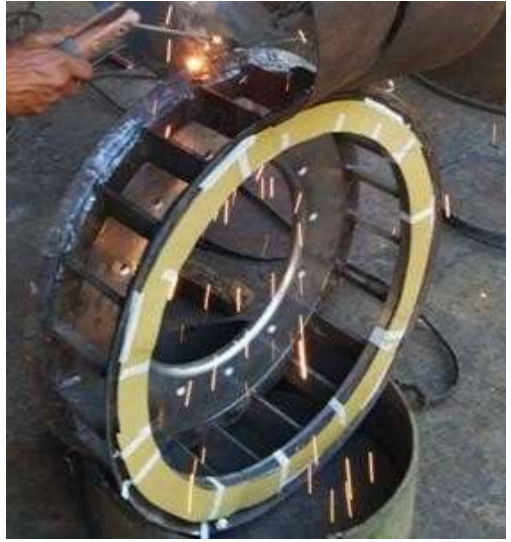

Gambar 6. Proses pembuatan dudukan poros turbin propeller

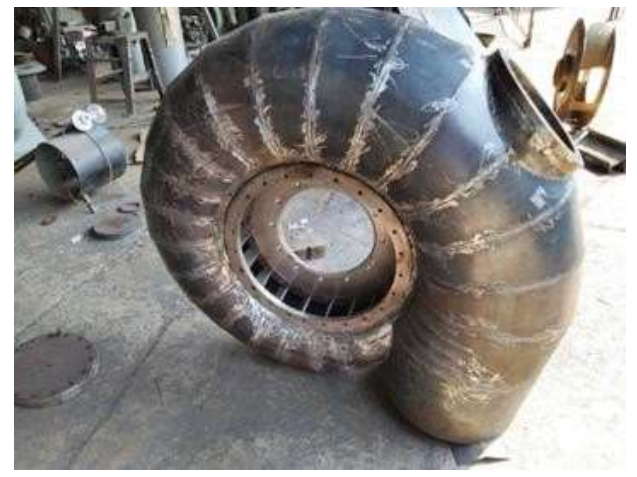

Gambar 7. Hasil pembuatan turbin propeller

Pabrikasi komponen turbin dikerjakan oleh bengkel mekanik lokal. Hampir 90\% pekerjaan dikerjakan oleh mekanik lokal, sehingga dengan adanya tambahan pengalaman ini, diharapkan dapat meningkatkan perkembangan pembuatan turbin propeller di Indonesia. Mengingat, Indonesia merupakan negara yang memiliki sumber daya air yang potensial sebagai sumber energi pembangkit listrik tenaga mikrohidro. Gambar 8 adalah salah satu gambar hasil akhir penelitian terhadap desain turbin propeller:

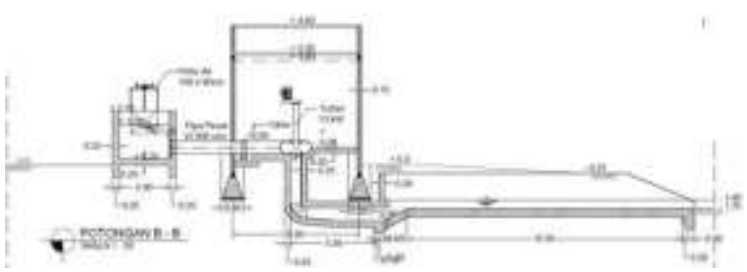

Gambar 8. Desain perletakan turbin propeller pada perencanaan PLTMH
Secara teknis, mikrohidro mempunyai tiga komponen utama yaitu air sumber energi, turbin dan generator. Air yang mengalir dengan kapasitas tertentu disalurkan dengan ketinggian tertentu melalui pipa pesat menuju rumah instalasi (power house). Di rumah instalasi, air tersebut akan menumbuk turbin sehingga akan menghasilkan energi mekanik berupa berputarnya poros turbin. Putaran poros turbin ini akan memutar generator sehingga dihasilkan energi listrik. Secara skematis ditunjukkan pada gambar berikut ini :

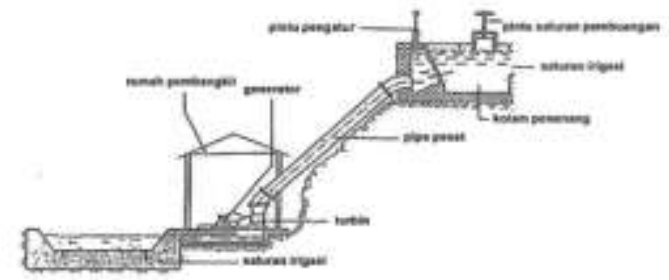

Gambar 9. Proses Pembangkitan Listrik Tenaga Air

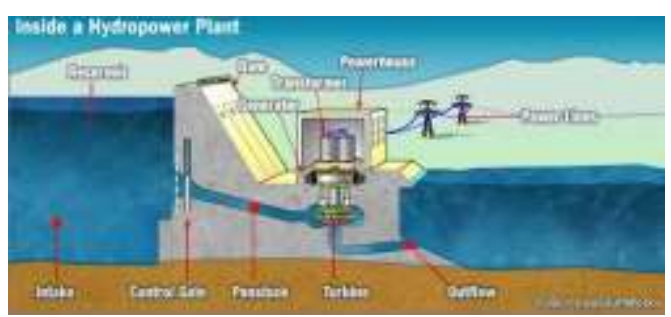

Gambar 10. Skema PLTMH
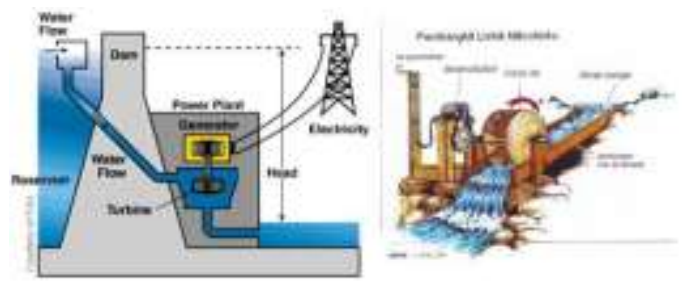

Gambar 11. Skema PLTMH

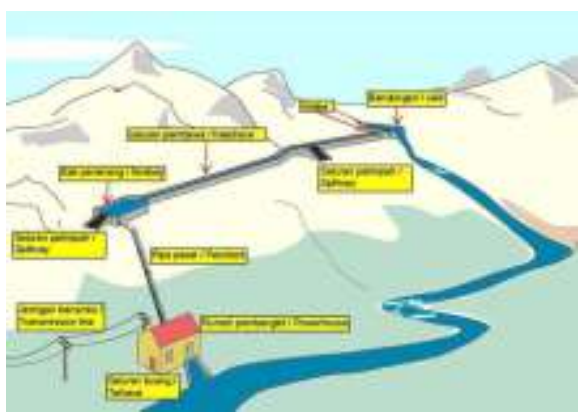

Gambar 12. Komponen PLTMH 


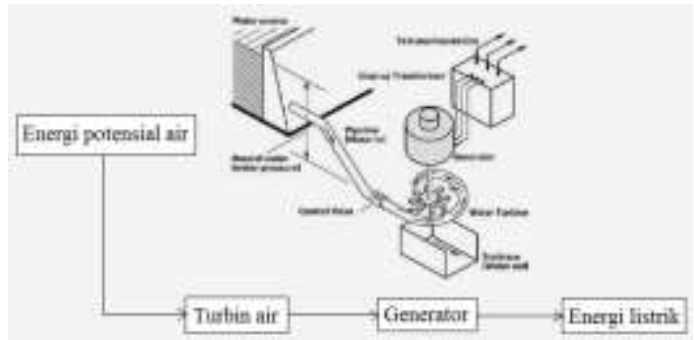

Gambar 13. Prinsip Kerja PLTMH

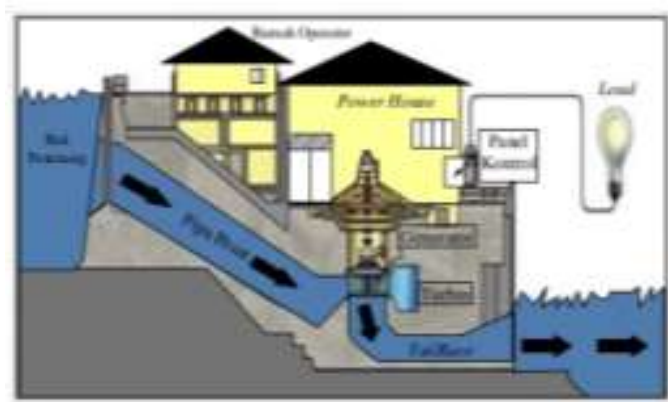

Gambar 14. Skema Kerja PLTMH

Rancangan Turbin kemudian dibuat rancangan turbin seperti ditunjukkan pada gambar berikut:

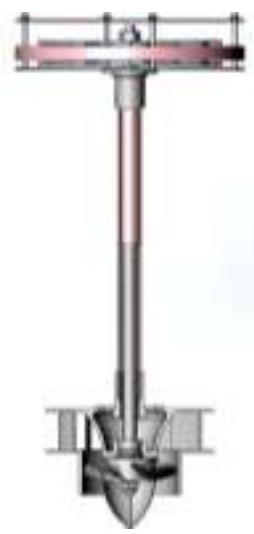

Gambar 15. Turbin propeller-Vanes Rumah Turbin

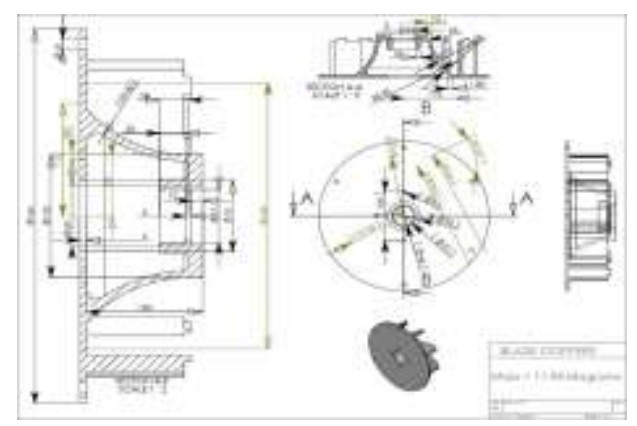

Gambar 16. Sudu Pengarah

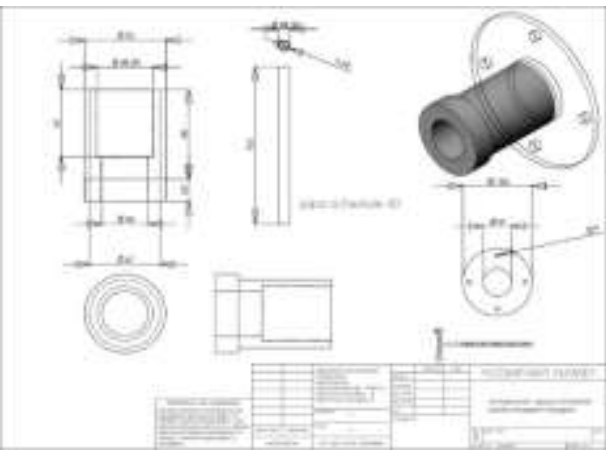

Gambar 17. Dudukan bantalan generator

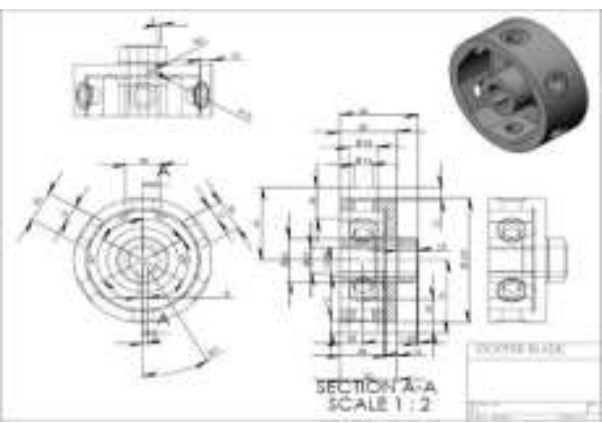

Gambar 18. Dudukan sudu jalan

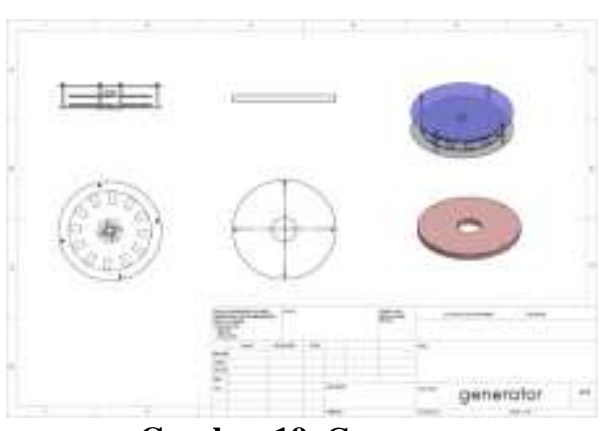

Gambar 19. Generator

\section{KESIMPULAN}

Dari hasil penelitian diperoleh kesimpulan yaitu : 1) Dengan potensi debit desain turbin propeller dapat digunakan diameter sudu (D1) $=332 \mathrm{~mm}$, diameter hubung/leher poros $(\mathrm{DN})=133 \mathrm{~m}$ dan diameter sudu pengarah $(\mathrm{Do})=398,5 \mathrm{~mm}$; 2) Desain jumlah putaran turbin per menit adalah 500 radial per menit (rpm) yang menghasilkan kecepatan spesifik $(\mathrm{nq})=203$; dan 3) Turbin di pabrikasi di bengkel mekanik lokal sehingga dapat meningkatkan pengalaman dalam pembuatan turbin propeller untuk PLTMH. 
DAFTAR PUSTAKA KELAYAKAN

PEMBANGUNAN

PEMBANGKIT

LISTRIK

TENAGA MIKROHIDRO Studi

Kasus: PLTMH Minggir pada saluran irigasi Minggir di

Padukuhan Klagaran Desa

Sendangrejo Kecamatan Minggir

Kabupaten Sleman," J. UNSA

Prog., vol. 10, no. 15, pp. 93-111,

2011, doi: 10.31227/osf.io/9nkym.

[2] D. Mulyani and D. Hartono, "Pengaruh Efisiensi Energi Listrik pada Sektor Industri dan Komersial terhadap Permintaan Listrik di Indonesia," J. Ekon. Kuantitatif Terap., p. 1, 2018, doi: 10.24843/jekt.2018.v11.i01.p01.

[3] K. Nissa and S. Suwignyo, "Desain dan Pembuatan Turbin Propeller," Pros. SENTRA (Seminar Teknol. dan Rekayasa), no. 4, pp. 90-96, 2019, [Online]. Available: http://research-

report.umm.ac.id/index.php/sentra/ article/view/2196.

[4] Kementerian Energi dan Sumber Daya Mineral, Rencana Umum Ketenagalistrikan Nasional 2019 2038. 2019.

[5] I. R. dan W. Hermawati and Pusat, "Dampak listrik PLTMH terhadap kehidupan sosial ekonomi masyarakat di Dusun Gunung Sawur, Desa Sumber Rejo, Candipuro, Lumajang," in Prosiding Konferensi dan Seminar Nasional Teknologi Tepat Guna, 2014, pp. 456-507.

[6] V. Dwiyanto, D. Indriana K., and S. Tugiono, "Analisis Pembangkit Listrik Tenaga Mikro Hidro (PLTMH) Studi Kasus : Sungai Air Anak (Hulu Sungai Way Besai)," $J$. Rekayasa Sipil dan Desain, vol. 4, no. 3, pp. 407-422, 2018.

[7] E. Ariyanto, I. Setiono, P. Sasmoko, and Z. A. Pamungkas, "Eksistensi PLTMH Cinta Mekar Dalam Pemberdayaan Masyarakat Melalui Koperasi Mekar Sari di Desa Cinta Mekar Kecamatan Serang Panjang Kabupaten Subang Provinsi Jawa Barat," Gema Teknol., vol. 19, no. 4, pp. 31-36, 2018 , doi: 10.14710/gt.v19i4.19154.

[8] M. D. Trisno, M. Firdausi, and D. Dahlan, "Perancangan Turbin Mikrohidro Tipe Propeler Vanes Kapasitas 1000 Watt," in Seminar Nasional Teknik Mesin 7, 2012, pp. 3-8. 